\title{
MOBILE APPLICATION FOR PRACTISING MATRICES AND GRAPHS
}

Patrik VOŠTINÁR*, Univerzita Mateja Bela v Banskej Bystrici, Slovenská republika

Erik PATRÁŠ, Univerzita Mateja Bela v Banskej Bystrici, Slovenská republika

Přijato: 30. 7. 2019 / Akceptováno: 18. 12. 2019

Typ článku: Teoretická studie

DOI: $10.5507 /$ jtie.2019.013

Abstract: The popularity of smartphones and expansion of their usage into various areas in the last years caused that users want to have to control everything on their phone. The paper deals with the description of the educational mobile application for practicing operations with matrices and graphs. The created mobile app is free, available in the Google Play Store. The main functionality of the application is the possibility of practicing unlimited operations with matrices and graphs. The main aim of creating this application is to create an educational tool that can improve the motivation to study the subject Discrete Mathematics for Computer Science.

Key words: mobile applications, Android, matrices, graphs.

\section{MOBILNÁ APLIKÁCIA PRE PRECVIČOVANIE MATÍC A GRAFOV}

Abstrakt: Popularita inteligentných telefónov a rozšírenie ich využitia do najrôznejšich oblastí v posledných rokoch spôsobila potrebu použivatel'ov mat' všetko pod kontrolou vo svojom telefóne. Výnimkou nie je ani používanie týchto zariadení vo vzdelávaní. Príspevok sa zaoberá opisom vzdelávacej mobilnej aplikácie pre precvičovanie operácii s maticami a grafovými úlohami. Vytvorená mobilná aplikácia je bezplatná, dostupná v obchode Google Play. Hlavnou funkcionalitou aplikácie je možnost' neobmedzeného precvičovania operácií s maticami a grafovými úlohami. Hlavným cielom vytvorenia tejto aplikácie je vytvorenie didaktickej pomôcky, ktorá môže zlepšit motiváciu k štúdiu predmetu diskrétna matematika pre informatikov.

Klíčová slova: mobilné aplikácie, Android, matice, grafy.

\footnotetext{
*Autor pro korespondenci: patrik.vostinar@umb.ck
} 


\section{1 Úvod}

Počas svojej existencie sa mobilné telefóny vyvinuli zo zariadení, ktoré mali ul'ahčit' telefonovanie na zariadenia, ktoré sú schopné nahradit' desiatky, ak nie stovky iných zariadení a prístrojov, ktoré l'udia môžu využivat' denne alebo len vel'mi zriedka. Jednoduchost' ich používania a fakt, že sú schopné ul'ahčit' množstvo l'udských činností viedlo k ich preniknutiu aj do vzdelávania.

Drigas a Pappas (2016) uviedli, že vzdelávanie online a pomocou mobilných zariadení bolo pre študentov motivujúcejšie a matematické kurzy boli pre nich viac prítažlivejšie ako klasické vyučovanie. Bayerl a Žilková (2017) vo svojich výskumoch uviedli, že používanie iBooks učebníc na tabletoch nie je iba alternatíva k tradičnej forme vyučovania, ale v niektorých ohl'adoch prekročilo ich očakávania. Pokorný (2013) vo svojom výskume, ktorý realizoval v rokoch 2010-2013 dokázal, že študenti, ktorí riešili matematické problémy s použitím interaktívnych prvkov boli úspešnejší ako študenti, ktorí pri riešení nepoužívali interaktívne prvky.

V súčasnosti existuje vel'ké množstvo rôznych mobilných vzdelávacích aplikácií. Najväčšou nevýhodou týchto aplikácií je, že neobsahujú slovenský alebo český jazyk, ktorý je potrebný pre aplikácie zamerané na primárny stupeň vzdelávania na slovenských školách. Postupne však vznikajú aj aplikácie obsahujúce slovenský, resp. český jazyk. Fialová (2018) vytvorila a otestovala aplikácie Mayské počitanie pre detičky ${ }^{1}$ a Egyptské násobenie a delenie ${ }^{2}$. Aplikácia Mayské počitanie pre detičky je zameraná na sčítanie a odčítanie prirodzených čísel zapísaných neštandardným spôsobom v semipozičnej číselnej sústave. Aplikácia Egyptské násobenie a delenie na násobenie a delenie pomocou metódy zdvojovania.

Matice sú už oddávna dôležitou súčast'ou matematiky, vedy a výskumu. Patria medzi vyučovacie osnovy na stredných školách a majú mnohé každodenné využitia o ktorých vel'a l'udí ani nevie. S rozvojom mobilných telefónov prišla príležitost' zapojit' matice viac do l’udského života vo forme mobilných aplikácií. V súčasnosti existuje niekol'ko aplikácií zameraných na matice, väčšina z nich však poskytuje iba základné operácie. Z tohto dôvodu sme sa rozhodli vytvorit’ mobilnú aplikáciu zameranú na precvičovanie riešenie maticových problémov.

\section{Vývoj mobilných aplikácií}

Aktuálne na trhu dominujú hlavne zariadenia s operačným systémom Android a iOS. Viaceré spoločnosti vykonávajú rôzne štatistiky rozšíritel'nosti mobilných operačných systémov. Podl’a štatistickej stránky statcounter (Mobile Operating System Market Share Worldwide, 2019) k máju 2019 Android zariadenia tvorili až 75.27\% trhu. Zariadenia so systémom iOS boli druhé v poradí s podielom $22.74 \%$. Medzi d’alšie známe OS určenými pre mobilné zariadenia, ktoré sa dajú nájst’ na trhu je napríklad KaiOS s 0.75\%, ktorý je open source nástupcom Firefox OS od spoločnosti Mozilla (vývoj Firefox OS sa ukončil v roku 2016) alebo Windows 10 Mobile s 0.24\%.

\footnotetext{
${ }^{1}$ Dostupné na: https://play.google.com/store/apps/details?id=appinventor.ai_jankafialka2357.Mayovia10

${ }^{2}$ Dostupné na: https://play.google.com/store/apps/details?id=appinventor.ai_jankafialka2357.Zdvojnasobovanie
} 


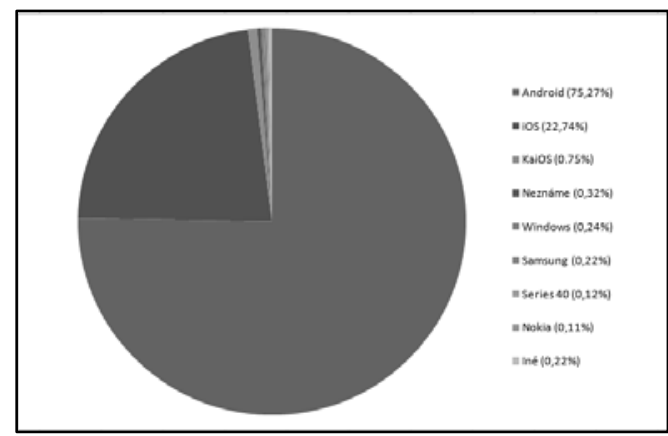

Obr. č. 1: Graf zastúpenia mobilných OS na trhu (Mobile Operating System Market Share Worldwide, 2019).

Prvým krokom, ktorý musíme urobit’ pred začatím vývoja mobilnej aplikácie je rozhodnút' sa pre aký mobilný operačný systém chceme vytvorit’ aplikáciu. Každý mobilný operačný systém má svoj vlastný programovací jazyk, ktorý musíme použit’ pri vytváraní softvéru. Aplikácie pre systém iOS sa vytvárajú v programovacom jazyku Swift, alebo môžeme použit' aj starší programovací jazyk Objective-C. Aplikácie pre Android je možné vytvárat' pomocou jazyka Java, alebo pomocou nového programovacieho jazyka Kotlin. V prípade vytvárania mobilných aplikácií pomocou niektorého z vyššie uvedených programovacích jazykov hovoríme o tzv. natívnom vývoji mobilných aplikácií (pre každý operačný systém vytvoríme samostatnú aplikáciu). Výhoda tohto spôsobu vývoja aplikácií spočíva k plnej dostupnosti a kontrole nad vývojom aplikácií. Najväčšiu nevýhodu tohto spôsobu vývoja spočíva v nutnosti vyvíjat' samostatné aplikácie pre každý operačný systém.

Alternatívou k natívnemu vývoju aplikácií je tzv. multiplatformový vývoj aplikácií. Aplikácie vyvíjané multiplatformovým vývojom sú na rozdiel od natívnych aplikácii kompatibilné s viacerými platformami (vytvárame jednu aplikáciu, ktorú vieme spustit' na viacerých platformách). Hlavnou nevýhodou takéhoto spôsobu vývoja aplikácií je menšia kontrola nad vývojom a tiež horšia optimalizácií na konkrétnom zariadení, čo môže spôsobit' spomalenie aplikácií.

Na základe štatistickej stránky statcounter (obr. č. 1) je najvýhodnejšie vytvárat' mobilné aplikácie pre operačný systém Android, ktorý dominuje na trhu s mobilnými zariadeniami.

\section{Mobilná aplikácia Matrices and Graphs}

Mobilná aplikácia Matrices and Graphs (po slovensky Matice a Grafy, d’alej len MaG) vznikla za účelom pomôct' študentom pri študovaní aplikovanej informatiky a učitel'stva informatiky v kombinácii na Univerzite Mateja Bela v Banskej Bystrici. Aplikácia ponúka funkcionalitu, ktorú môžu študenti využit’ na viacerých predmetoch ale aj mimo školy. Okrem študentov z katedry môžu túto aplikáciu používat' všetci používatelia, ktorí 
disponujú mobilným zariadením s OS Android a obchodom Play Store. Aktuálne je možné si aplikáciu MaG zadarmo stiahnut ${ }^{3}$ a nainštalovat' cez Google Play Store.

Aplikácia je dvojjazyčná - podporuje slovenčinu a angličtinu. Jazyk je zvolený na základe nastaveného jazyka v mobilnom zariadení. V prípade, že je nastavená slovenčina, tak je jazyk aplikácie slovenský, v opačnom prípade je jazyk aplikácie nastavený na anglický jazyk.

Po spustený aplikácie sa zobrazí hlavné menu, ktoré obsahuje tri tlačidlá (obr. 2).

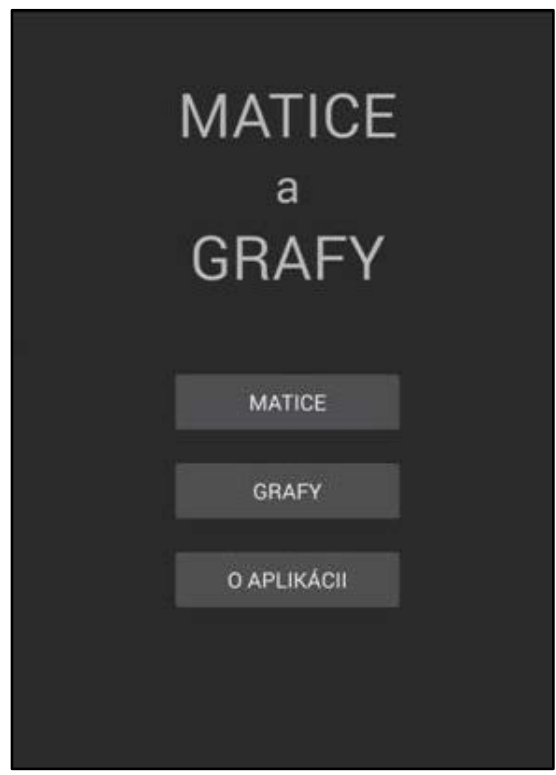

Obr.č. 2: Hlavné menu aplikácie.

Na precvičovanie základných operácí s maticami je potrebné stlačit' prvé tlačidlo Matice. Používatel' si môže otestovat' ako ovláda počítanie s maticami tým, že si nechá vygenerovat' príklad, ktorý skúsi sám vyriešit' a potom si môže porovnat' výsledky $\mathrm{s}$ aplikáciou. $\mathrm{V}$ tomto móde má používatel' na vyber niekol'ko možností. Ako prvé si používatel' môže vybrat' akú matematickú operáciu s maticami chce vykonávat'. Aplikácia ponúka sedem základných operácií s maticami (obr. 3a):

- sčítanie,

- odčítanie,

- roznásobenie dvoch matíc,

- vynásobenie matice skalárnom,

- výpočet inverznej matice,

- determinantu matice,

\footnotetext{
${ }^{3}$ Dostupné na: https://play.google.com/store/apps/details?id=com.mag.sion.matice
} 
- $\quad$ vyriešenie sústavy rovníc zapísanej v matici.

Používatel' si tiež môže vybrat', či chce aby mu aplikácia sama vygenerovala hodnoty do matíc z rozsahu, ktorý sám zadá, alebo si hodnoty do matice vypíše sám. Následne zadá rozmery matice alebo matíc s ktorými chce pracovat' a s akou presnost'ou/zaokrúhl'ovaním má aplikácia počítat' (obr. 3b). Následne sa používatel'ovi zobrazí plocha s dvoma maticami a panelom s jedným alebo viacerými tlačidlami (obr. 3c). Horná matica je vstupná matica, do ktorej používatel' zadáva hodnoty aké potrebuje. Ak sú na vstupe potrebné dve matice, zobrazí sa na paneli s tlačidlami tlačidlo M1, ktorým používatel' prepína medzi vstupnými maticami. Dolná matica je výstupná matica. Na výstupnej matici sa používatel'ovi po stlačení tlačidla vyrieš zobrazí výsledok. Ak si používatel' nechal vygenerovat' hodnoty v matici aplikáciou, na paneli tlačidiel bude tlačidlo Reset, pomocou ktorého používatel' môže nechat' aplikáciu vygenerovat' nové hodnoty do matice.

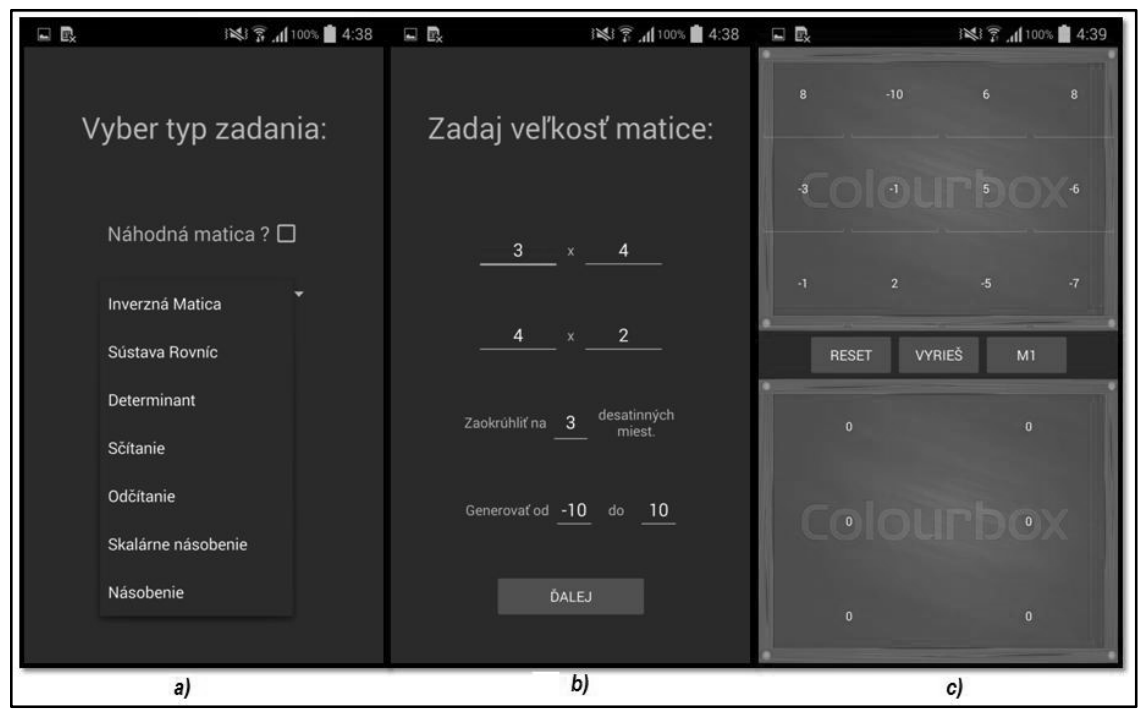

Obr. č. 3: Mobilná aplikácia - ukážka počitania s maticami.

Čast’ práca s grafmi slúži hlavne na aplikáciu vybraných grafových algoritmov na graf, ktorý použivatel' zadá. Aplikácia zatial' implementuje pät' grafových algoritmov (obr. 4a):

- Dijkstrov algoritmus,

- $\quad$ Floyd-Warshallov algoritmus na nájdenie najkratšej cesty v grafe,

- výpočet tranzitívneho uzáveru grafu,

- Fleuryho algoritmus na nájdenie Eulerovho t’ahu a cyklu,

- $\quad$ Ford-Fulkerssonov algoritmus na nájdenie maximálneho prietoku v grafe.

V tejto časti aplikácie si používatel' môže vybrat' spôsob, akým bude reprezentovat' graf. Aplikácia umožňuje používatel'ovi dva spôsoby zadania grafu. Prvý je pomocou 
matice susednosti (obr. 4b), kedy používatel' najprv zadá počet vrcholov v grafe a potom vyplní hodnoty hrán v matici ktorá sa mu vygeneruje. Druhý spôsob je nakreslením (obr. $4 c$ ), kedy používatel' pomocou grafického rozhrania nakreslí graf na plátno v aplikácií, čo aplikácia následne automaticky spracuje do matice po stlačení tlačidla Vyrieš. Používatel' si potom môže zo zoznamu vybrat', ktorý algoritmus chce aplikovat' na graf, ktorý zadal, a stlačením tlačidla Vyrieš mu aplikácia vypíše alebo vykreslí výsledok.

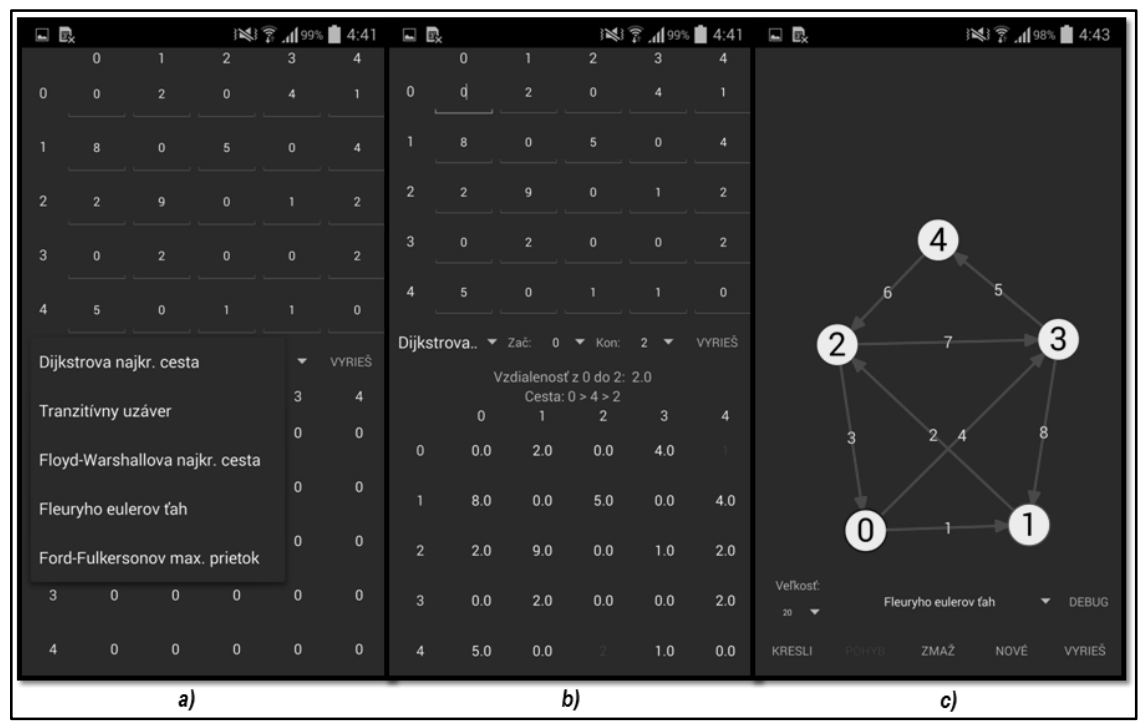

Obr. č. 4: Mobilná aplikácia - ukážka počítania s grafmi.

\section{Testovanie aplikácie a metodika výskumu}

Aplikáciu sme sa rozhodli otestovat' na predmete Diskrétna matematika, ktorý sa vyučuje v prvom ročníku bakalárskeho štúdia. Na tento predmet bolo prihlásených:

- 35 denných študentov Aplikovanej informatiky,

- 11 študentov odboru učitel'stvo informatiky v kombinácii,

- 8 externých študentov Aplikovanej informatiky.

Z celkového počtu 54 študentov vyplnilo dotazník 39 študentov. Pri prezentácií aplikácie však neboli prítomní všetci študenti, nakol'ko čast' z nich už vôbec nechodila na prednášky a cvičenia (resp. opakovali tento predmet a na prednášky nechodili).

Ciel'om výskumu bolo zistit', či použivanie vhodných didaktických mobilných aplikácií môže zlepšit študijné výsledky a motiváciu $k$ štúdiu daného predmetu. Z tohto dôvodu sme vytvorili postojový dotazník pomocou stránky Forms Google 4 . Dotazník obsahoval 7 otázok.

\footnotetext{
${ }^{4}$ Dostupné na: https://docs.google.com/forms/d/e/1FAIpQLSestO2XrDO4TyL5W5IY6r4I_ZctTIbm0zmX5nbHghh aa-OQiA/viewform
} 
V otázke „Páčila sa ti aplikácia Matrices and graphs?“ sme zist’ovali, či sa študentom páčila aplikácia (obr. 5). Respondenti odpovedali, že väčšine sa páčila $(74,4 \%)$ a zvyšným 25,6\% respondentom sa skôr páčila, ako nepáčila.

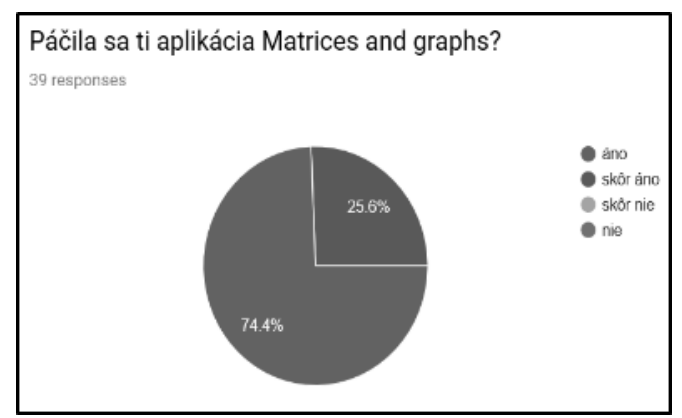

Obr. č. 5: Postojový dotazník - hodnotenie vzhladu a funkcionality aplikácie.

Pomocou otázky „Pomohla ti pri štúdiu predmetu Diskrétna matematika (Dijkstrov algoritmus, grafy)?“" sme chceli zistit', či je táto aplikácia vhodná ako pomocný materiál pri štúdiu Dijkstrovho algoritmu (overovaniu výsledkov, precvičovaniu rátania). 30,8\% respondentov odpovedalo, že im aplikácia pomohla pri štúdiu, 61,5\% respondentov odpovedalo, že skôr pomohlo a 7,7\% odpovedalo, že im nepomohla aplikácia (obr. 6).

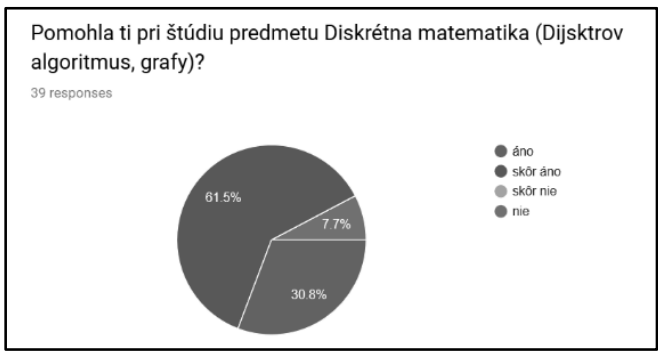

Obr. č. 6: Postojový dotazník - pomohla ti aplikácia pri štúdiu predmetu Diskrétna matematika?

V otázke „Čo všetko si využival v aplikácii?“" sme chceli zistit, čo všetko študenti skúšali v aplikácii (obr. 7). Z výsledkov vyplynulo, že najviac (87,20\%) respondentov používalo v aplikácií úlohy na precvičovanie Dijkstrovho algoritmu a operácie s grafmi kreslenie matíc $(71,80 \%)$. 


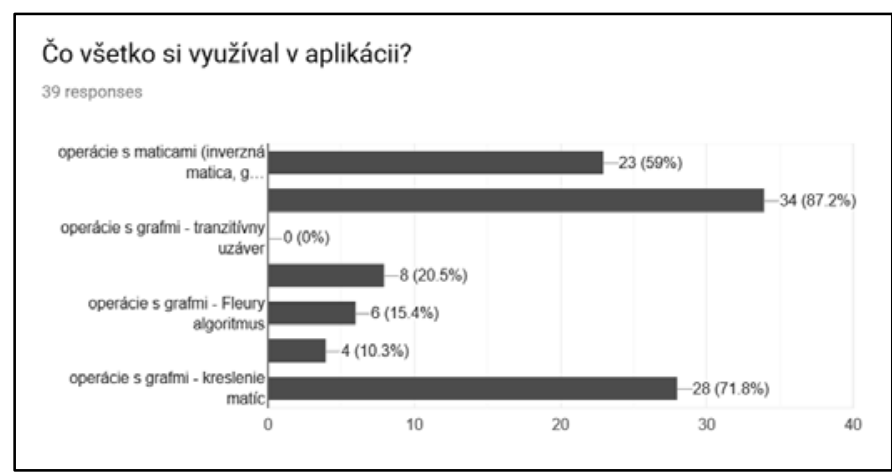

Obr. č. 7: Postojový dotazník - zist’ovanie využitel’nosti jednotlivých častí aplikácie.

Predpokladáme, že aplikácia je vhodná aj na iné predmety počas štúdia informatiky. Pomocou otázky „Myslíš si, že aplikáciu budeš využívat' pri iných predmetoch, kde sa bude pracovat' s maticami?"“ sme chceli zistit', či si študenti myslia, že im táto aplikácia ešte v budúcnosti pomôže, alebo si ju hned' vymažú z mobilného zariadenia (obr. 8). Skoro všetci respondenti uviedli, že si myslia, že ešte budú pracovat' s maticami (46,20\% áno, 48,70\% skôr áno).

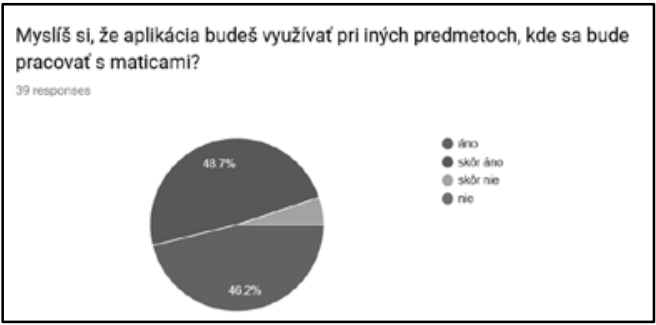

Obr. č. 8: Postojový dotazník - využitie mobilnej aplikácie do budúcnosti.

V d’alšej dotazníkovej otázke sme chceli zistit', či majú respondenti nejaké d'alšie návrhy na zmeny. Najčastejšie respondenti odpovedali, že nemajú žiadne pripomienky, niektorí napísali, že by chceli aby bolo možné aplikáciu spustit' aj na mobilnom operačnom systéme iOS (obr. 9). 


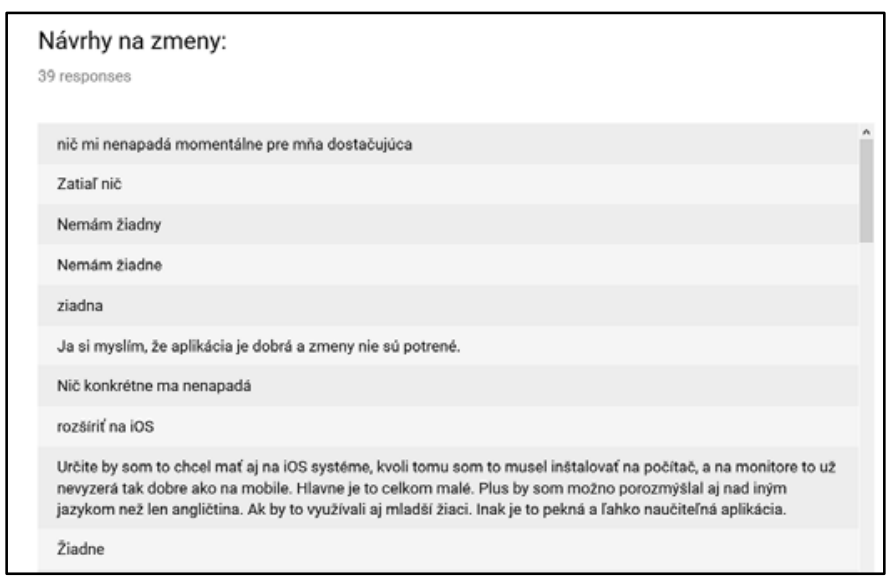

Obr. č. 9: Postojový dotazník - návrhy na zmenu aplikácie.

V poslednej otázke sme zist'ovali, či respondenti nechcú niečo odkázat' vývojárovi aplikácie. Odpovede na tejto otázke boli vel'mi podobné odpovediam z predchádzajúcej otázky - že má autor pokračovat' vo vytváraní aplikácií a rozšríit aplikáciu aj pre mobilný operačný systém iOS (obr. 10).

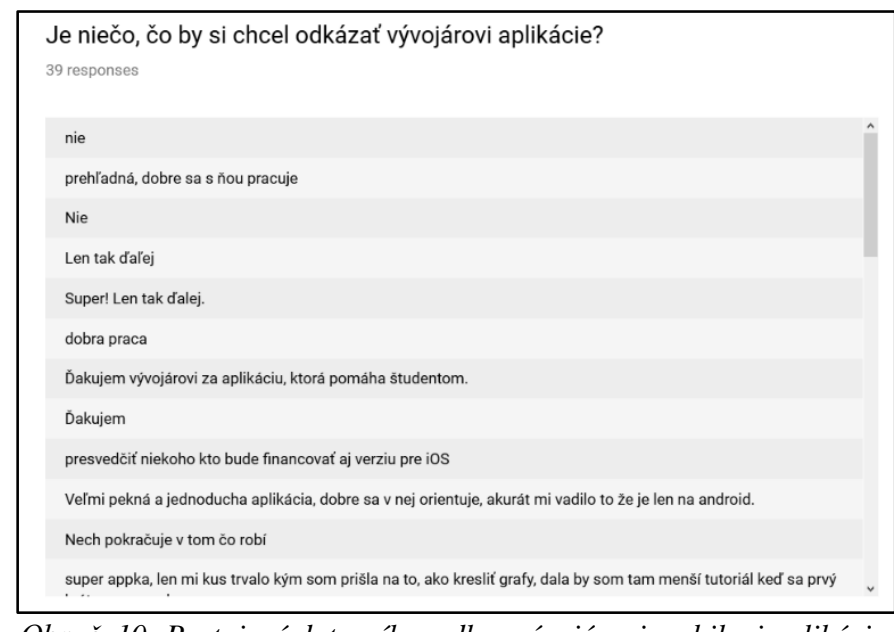

Obr. č. 10: Postojový dotazník - odkaz vývojárovi mobilnej aplikácie.

\section{Diskusia}

Na základe výsledkov z dotazníka môžeme zhodnotit', že sa aplikácia študentom učitel'stva informatiky $\mathrm{v}$ kombinácií a študentom aplikovanej informatiky páčila. Študentom pomohla pri štúdiu Dijkstrovho algoritmu a tiež s inými grafovými algoritmami. Na základe dotazníka môžeme povedat', že študenti budú chciet' používat' 
aplikáciu aj pri d’alšom štúdiu. V návrhoch na zmenu sa viackrát objavila požiadavka na vytvorenie aplikácie pre operačný systém iOS. Pár negatívnych hodnotení sa týkalo dizajnu aplikácie - nakol’ko si však myslíme, že nemáme grafické nadanie, rozhodli sme sa dizajn zatial' nechat' tak a $\mathrm{v}$ budúcnosti na ňom popracovat' spolu s grafickými návrhármi.

Na základe výsledkov z dotazníka môžeme predpokladat', že používanie vhodných didaktických mobilných aplikácií môže zlepšit študijné výsledky a motiváciu k štúdiu daného predmetu. Toto zhodnotenie dokazujú aj d’alšie výskumy vplyvu mobilných zariadení pri výučbe.

Používaním mobilných zariadení vo výučbe matematiky sa zaoberal výskum na gymnáziu v Banskej Bystrici, kde autori vytvorili interaktívne materiály pre výučbu geometrie. Výsledky ukázali pozitívny vplyv používania matematických mobilných aplikácii vo vyučovaní (Bayerl, Žilková, 2016).

Ďalší výskum dokazuje, že 39\% študentov používa mobilné zariadenia pri riešení domácich úloh, iba $6 \%$ z nich ich však môže používat' vo výučbe (Nielsen, 2013).

Výskum zo Škótska potvrdzuje pozitívny vplyv mobilných zariadení vo výučbe. Žiaci počas výskumu používali mobilné zariadenia po celú výučbu, v určitých situáciách a čast' i mimo školy. Rodičia žiakov uviedli väššiu motiváciu k výučbe. A zlepšenie študijných výsledkov (Burden, 2012).

V Českej republike prebiehal dotazníkový prieskum medzi učitel’mi základných škôl na využívanie tabletov vo výučbe. $Z$ výskumu vyplynulo, že tieto zariadenia sa pomaly stávajú bežnou súčast'ou výučby, pričom $40 \% \mathrm{z}$ respondentov uviedlo, že chcú pokračovat' vo výučbe s mobilnými zariadeniami, 15\% uviedlo, že nedisponujú školskými tabletmi a preto ich nevyužívajú (Benediktová, 2017).

\section{Záver}

V príspevku sme stručne opísali rôzne spôsoby vývoja mobilných aplikácií. Každý z uvedených spôsobov má svoje výhody a nevýhody. V príspevku sme predstavili mobilnú vzdelávaciu aplikáciu vytvorenú v prostredí Android Studio (natívne pre operačný systém Android). Aplikácia umožňuje generovat' neobmedzené množstvo úloh zameraných na operácie s maticami a vybranými grafovými úlohami. Na základe testovania predpokladáme, že aplikácia je vhodná pre študentov stredných a vysokých škôl, ktorí ju môžu využit' pri svojom štúdiu, ale aj pre bežných l'udí, ktorí majú riešit' niektorý z problémov, na ktorý sa dajú aplikovat' naprogramované algoritmy. Aplikáciu by sme chceli v budúcnosti rozširovat' o d'alšie úlohy s vybranými grafovými úlohami a podrobit' výskumu na väššej vzorke.

Pri používaní mobilných vzdelávacích aplikácií je však potrebné venovat' väčšiu kontrolu nad aktivitami študentom, hlavne na základných a stredných školách, nakol'ko títo študenti môžu často robit' iné aktivity, ako od nich vyžaduje učitel' (odporúčame použit' špeciálny softvér určený na vzdelávanie s tabletmi - na kontrolu aktivít používatel’ov). 


\section{Literatúra}

Bayerl, E. \& Žilková, K. (2016). Interactive Textbooks in Mathematics Education - What Does It Mean for Students?. In 15th Conference on Applied Mathematics Aplimat 2016. Bratislava: Slovak University o Technology in Bratislava. pp. 56-65.

Bayerl, E. \& Žilková, K. (2017). The impact of iBooks on Geometric conceptions of students about isometries. In 16th Conference on Applied Mathematics Aplimat 2017. Bratislava: Slovak University o Technology in Bratislava. pp. 81-90.

Benediktová, L. (2017). Využití tabletů z pohledu učitelů ZŠ. In Journal of Technology and Information Education.

Burden, K. et al. (2012). iPad Scotland Evaluation. Dostupné z: http://www.tabletacademy.com/uploads/news/Scotland-iPad-Evaluation.pdf.

Drigas, S. \& Pappas, A. (2015). A review of Mobile Learning Applications for Mathematics. In International Journal of Interactive Mobile Technologies (iJIM) 9. Wien : International Association of Online Engineering. pp. 18-23.

Fialová, J. (2018). Tvorba a využitie aplikácií pre mobilné telefóny v školskej matematike. 2018. In EME Proceedings 2018, pp. 14-18.

Fialová, J. (2018). Využitie mobilných aplikácií vo výučbe sčítania a odčítania v l'ubovol'nej číselnej sústave. In Education-Technology-Computer Science in building better future, pp. 45-50.

Nielsen, L. (2013). Finally! Research-based proof that students use cell phones for learning. Dostupné z: http://theinnovativeeducator.blogspot.cz/2013/02/finally-researchbased-proof-that.html.

Pokorný, M. (2013). Interactive Elements Can Increase the Efficiency of e-learning Course. In Information, Communication and Education Application, Advances in Education Research. Vol. 30. pp. 173-178.

Statcounter (2019). Mobile Operating System Market Share Worldwide. Dostupné z: http:/gs.statcounter.com/os-market-share/mobile/worldwide. 